\title{
ANALYSIS OF MATERIAL NON-LINEARITY OF STEEL GIRDERS SUBJECTED TO PATCH LOADING
}

\author{
Dragana Turnić, Nenad Marković, Tomislav Igić, Vlastimir Nikolić, Marija Spasojević-Šurdilović
}

Subject review

The paper presents an analysis of behaviour of plate girders (welded steel I girders) under patch loading. Concentrated or uniformly distributed loading on a short length of the flange, and in the plane of web is known as patch loading. Behaviour of the girder in non-linear area, as well as the ultimate load capacity, which is manifested by buckling in the loaded zone were analysed. Girder modelling was performed in ANSYS Workbench 15 software [1]. In accordance with the standing regulations EN 1993-1-5 [2] and BSK 07 [3], in the course of the numerical analysis, six different material models were employed. The obtained results were compared to the experimentally obtained results.

Keywords: material nonlinearity; patch loading; steel girders; ultimate load capacity

Analiza nelinearnosti materijala limenih nosača podvrgnutih lokalnom opterećenju

Pregledni članak

U radu se daje analiza ponašanja limenih nosača (nosači od zavarenog čelika I) pod lokalnim opterećenjem. Koncentrirano ili jednoliko raspoređeno opterećenje na maloj udaljenosti od prirubnice i u ravnini mreže, poznato je kao lokalno opterećenje (patch loading). Analiziralo se ponašanje nosača u nelinearnom području kao i učinak kritičnog opterećenja, koji se manifestira izvijanjem. Za modeliranje nosača primijenjen je softver ANSYS Workbench 15 [1]. U skladu s važećim propisima EN 1993-1-5 [2] i BSK 07 [3], tijekom numeričke analize korišteno je šest različitih modela materijala. Dobiveni rezultati uspoređeni su s eksperimentalno dobivenim rezultatima.

Ključne riječi: limeni nosači; lokalno opterećenje; nelinearnost materiala; učinak kritičnog opterećenja

\section{Introduction}

Concentrated or uniformly distributed loading on a short length of the flange, and in the plane of web, of welded steel I girders (see Fig. 1) is known as patch loading [4]. In practical application, this type of load can be found in case of crane girder or during assembly of bridges when the bridge is being slid into designed position over the temporary or permanent supports etc. The forces occurring then can surpass the bearing capacity of the structure at certain points because of the patch loading, so the case of assembly can be relevant for design [5].

Due to its complexity, until now the comprehensive theoretical solution of this problem has not been found. For this reason, experimental research is of great importance as well as numerical modelling. As a basis for problem solving, experimental results obtained by $\mathrm{N}$. Marković will be used [6].

According to the experimental models, a numerical simulation of the girders in ANSYS Workbench 15 software was performed. Initial geometrical imperfections on the web were assumed for the girders, based on the experimental model. Numerical modelling of steel girders, loaded by patch loading was performed in compliance with the standing regulations EN 1993-1-5 [7] and six different material models were considered in nonlinear analysis.

We shall consider the girder behaviour in non-linear area, as well as the ultimate load capacity which is manifested by the occurrence of buckling in the loaded zone.

Two increases of the ultimate load capacity were analysed: the case when there is a longitudinal stiffener on the web, and the case the length of loading is increased from $50 \mathrm{~mm}$ to $150 \mathrm{~mm}$.
The results obtained by the numerical analysis were compared with experimentally obtained results.

\section{Experimental model}

The research presented in this paper included a part of experimental research conducted in 2003 at the Faculty of Civil Engineering of Podgorica by N. Marković from the Faculty of Civil Engineering of Belgrade. [6].

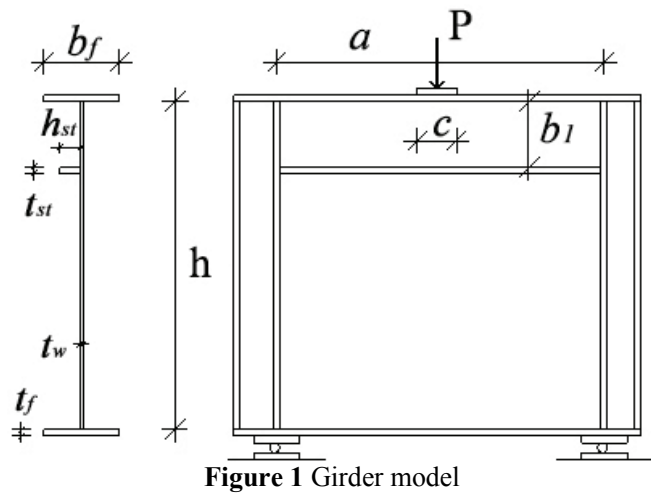

Table 1 Basic geometrical characteristics of girder mode

\begin{tabular}{|c|c|c|c|c|c|c|c|c|c|}
\hline \multirow{2}{*}{ Girder } & $a$ & $h$ & $t_{w}$ & $b_{f}$ & $t_{f}$ & $c$ & $h_{s t}$ & $t_{s t}$ & $b_{1}$ \\
\cline { 2 - 11 } & $\mathrm{mm}$ & $\mathrm{mm}$ & $\mathrm{mm}$ & $\mathrm{mm}$ & $\mathrm{mm}$ & $\mathrm{mm}$ & $\mathrm{mm}$ & $\mathrm{mm}$ & $\mathrm{mm}$ \\
\hline A1 & 500 & 500 & 4 & 120 & 8 & 50 & 0 & 0 & 0 \\
\hline A2 & 500 & 500 & 4 & 120 & 8 & 150 & 0 & 0 & 0 \\
\hline A3 & 500 & 500 & 4 & 120 & 8 & 50 & 30 & 8 & 100 \\
\hline A7 & 500 & 500 & 4 & 120 & 8 & 150 & 30 & 8 & 100 \\
\hline
\end{tabular}

Four types of girders of A series were considered having spans of $500 \mathrm{~mm}$ either without longitudinal stiffener or with longitudinal stiffener near the upper flange of the girder. The load was applied along the entire width of the top flange with the lengths of loaded sections 
of $50 \mathrm{~mm}$ and $150 \mathrm{~mm}$. A girder of A series with characteristic notations is presented in Fig. 1, and the dimensions are given in Tab. 1.

Preparation of the girders for the tests included marking of the grid on the web of the girders (Fig. 2), measuring of initial deformations and material characteristics testing. Measured initial deformations (geometrical imperfections) in characteristic points (see Fig. 3), were used for formation of the initial geometry of a girder in numerical modelling.

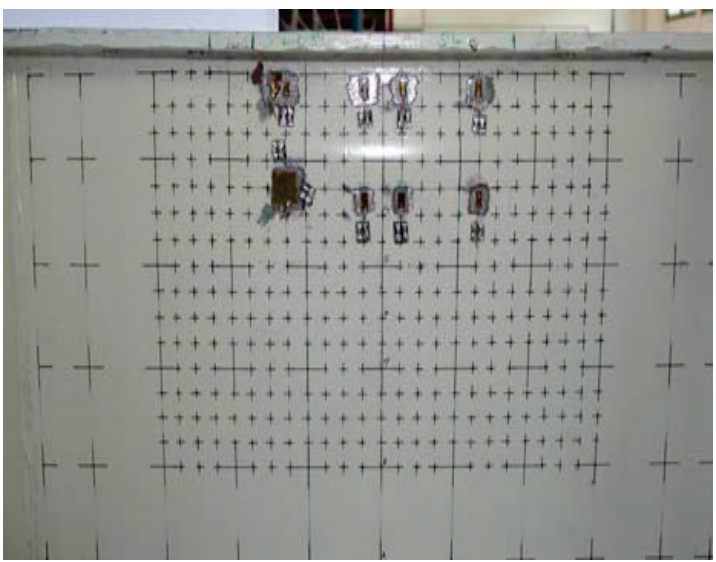

Figure 2 Grid marked on the girder (see [6])
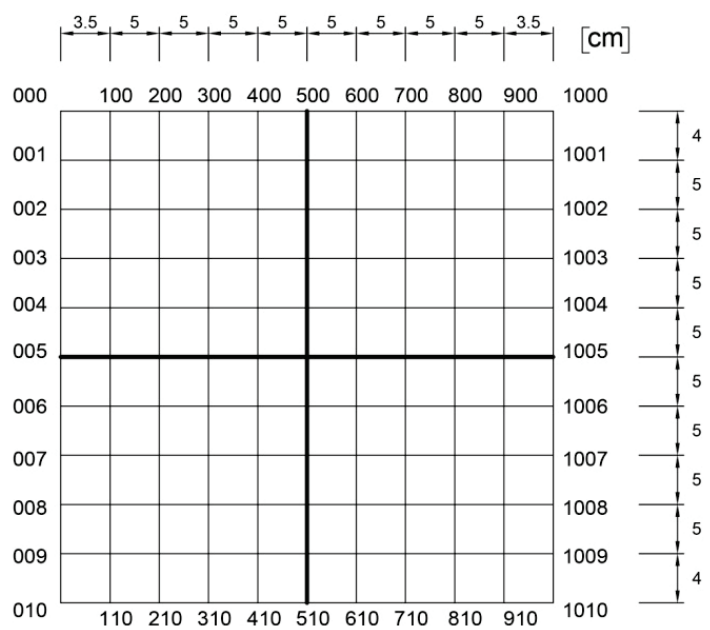

Figure 3 Grid plot of the points on the web where initial geometrical imperfections were measured

Material property tests were performed and the obtained results were used for formation of non-linear material models.

The girders were tested in specially designed closed frame (see Fig. 4). The load was applied by the press connected to the hydraulic pump. Initially the force was increased in large, and later in smaller load increments.

In the course of testing, lateral displacements were registered in the characteristic points of the web, as well as deflections at the middle of top and bottom flange. Strains were measured in a number of chosen points on the web and flange as well as the lateral displacements in the midspan cross section of the web after each load variations.

The load was increased until ultimate load was reached. The ultimate load was manifested as progressive increase of registered deformations of flanges and the web and strains without further increase of force. In the process, the visible buckling of the web below the zone where load was applied was observed. In case of the girders with longitudinal stiffener, the buckling is dominant between the loaded flange and the longitudinal stiffener.

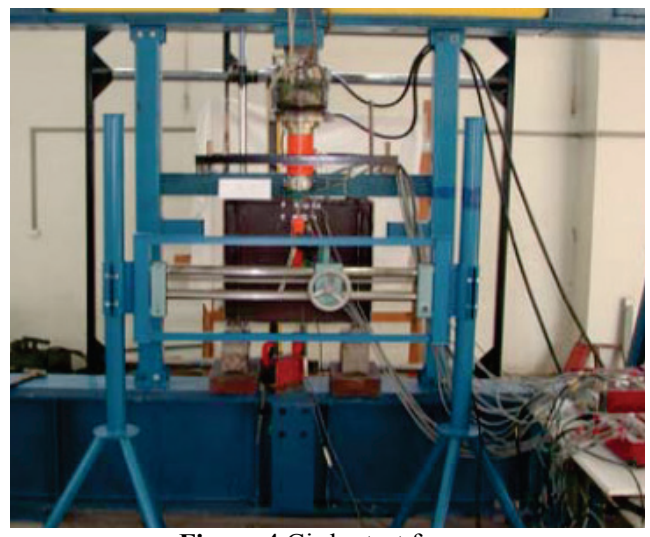

Figure 4 Girder test frame

After maximum load was kept for some time (different for the individual tests) the girders were unloaded and residual deformations of the webs and loaded flanges were measured. The deformations outside the web plane were measured in as many points as previously measured geometrical imperfections (see Fig. $3)$.

The results of the obtained ultimate loads are presented in Tab. 2.

\section{Girder numerical modelling}

Numerical modelling was performed in ANSYS Workbench 15 software [1]

Girder modelling included:

- Assigning of material properties and formation of material models;

- Formation of girder geometry with initial geometrical imperfections;

- Assigning of appropriate limit conditions as it was done in the experimental models;

- Assigning of loads as it was done in the experimental models;

- Discretization of the model using a mesh of finite elements;

- Assigning of appropriate analysis models parameters.

Formation of numerical models was performed so as to describe experimental models in the best possible way.

\subsection{Material models within non-linear analysis}

It is very important to assign the appropriate material behaviour parameters in a proper way in order to obtain relevant data using numerical analysis. As the steel girder is in question, its mechanical properties are determined on the basis of the modulus of elasticity, Poisson coefficient, compressive and tensile yield strength. It is assumed that the material is isotropic with identical values of mechanical properties in all directions.

For the purpose of obtaining as precise data as possible, the steel coupons cut out from the girder webs 
were tested. The coupons had the width of $12,5 \mathrm{~mm}$, and the length of $65 \mathrm{~mm}$. The obtained test results were used for formation of simplified material models of $\sigma-\varepsilon$ curves. The tests proved that the material corresponds to the steel class S275 and the $\sigma-\varepsilon$ diagram of material characteristics of one of the coupons is presented in Fig. 5. The diagrams $\sigma-\varepsilon$ of other coupons have the same shape and similar values.

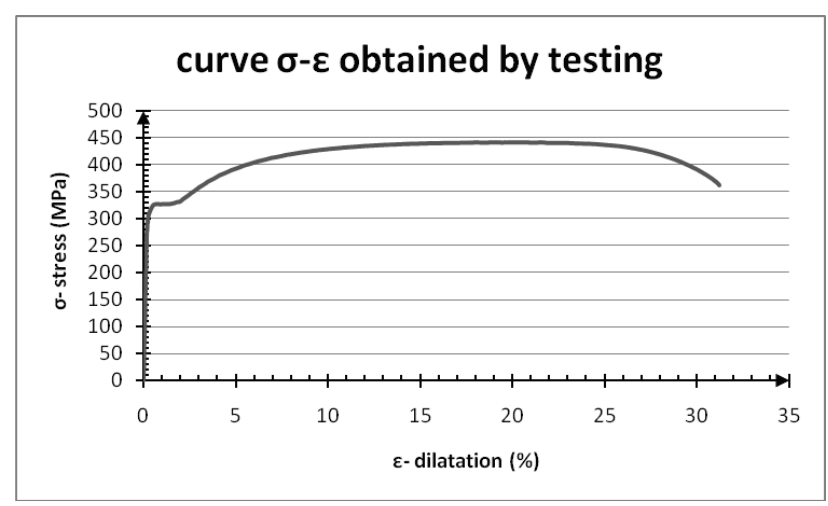

Figure 5 Material property diagram for a coupon (steel S275)

Recommendations for design EN-1993-1-5 Annex C, also concern the material property recommendations. Behaviour of structural steels is elasto-plastic. After reaching the yield point $f_{y}$ material no longer behaves in the linear-elastic manner, but becomes plasticized and strengthened, meaning that material non-linearity occurs. It is proposed, depending on the accuracy and availability of the data, usage of the following material models: bilinear stress-strain curve, in cases where material data are not available, the yield is theoretically assumed as a horizontal line, or the slope with the value $E / 10000$ is defined. The other case is approximation of the curve with the slope $E / 100$ where strengthening of material is considered. In case when as real presentation as possible is desired, it is possible to approximate the real curve in such a way to obtain a multilinear curve which will present the material characteristic in the best way if those data are available. According to BSK07, Swedish standards [3], a multilinear curve obtained by calculation presented in Fig. 6 is recommended. In this paper bilinear curves with the tangent modulus $E_{\mathrm{t}}=E / 10000, E_{\mathrm{t}}=$ $E / 1000$ will be used as given in the European standard EN1993-1-5 as well as $E_{\mathrm{t}}=E / 100$ and $E_{\mathrm{t}}=E / 12,5$ for an additional analysis. Multilinear curves recommended by EN1993-1-5 and BSK07 were used, in accordance with the data obtained in the mentioned laboratory tests in terms of characteristic values of stresses and strains.

Material modulus of elasticity is $210 \mathrm{MPa}$, Poisson coefficient is $v=0,3$. The used material models are based on the isotropic rule based on the theory of Von-Mises plasticity.

Within non-linear analysis, the values of stresses and strains were calculated on the basis of various material models in elastic-plastic area. This means that for instance, for the model A3, for the same girder, numerical simulation with five different ways of behaviours of the same material during loading until failure was performed according to the following:

- EN1993-1-5- multilinear curve corresponding to the real curve (Fig. 7);
- BSK07 (Swedish standard)-multilinear curve according to Fig. 6, and for the used models it is presented in Fig. 8;

- EN1993-1-5-bilinear with tangent modulus $E_{\mathrm{t}}=$ E/10000 (Fig. 9);

- Bilinear curve with tangent modulus $E_{\mathrm{t}}=E / 1000$ (Fig. 10), for additional analysis;

- EN1993-1-5-bilinear curve with tangent modulus $E_{\mathrm{t}}=$ E/100 (Fig. 11);

- $\quad$ Bilinear curve with tangent modulus $E_{\mathrm{t}}=E / 12,5$ (Fig. 12), for additional analysis.

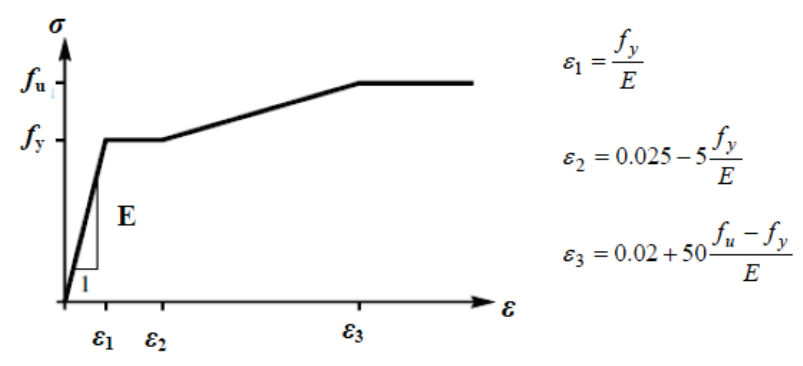

Figure 6 Multilinear material model according to the BSK 07 standard [3]

Approximation for the real curve $\sigma-\varepsilon$ (see Fig. 5) in several points was made. The values are increased to

$\sigma_{\text {true }}=\sigma(1+\varepsilon)$

And

$\varepsilon_{\text {true }}=\ln (1+\varepsilon)$

according to the European standard EN1993-1-5. The obtained multilinear curve is presented in Fig. 7. In this way, too, are obtained the values $f_{y}=329,97 \mathrm{MPa}$ and $f_{u}=$ 449,6 MPa [9].

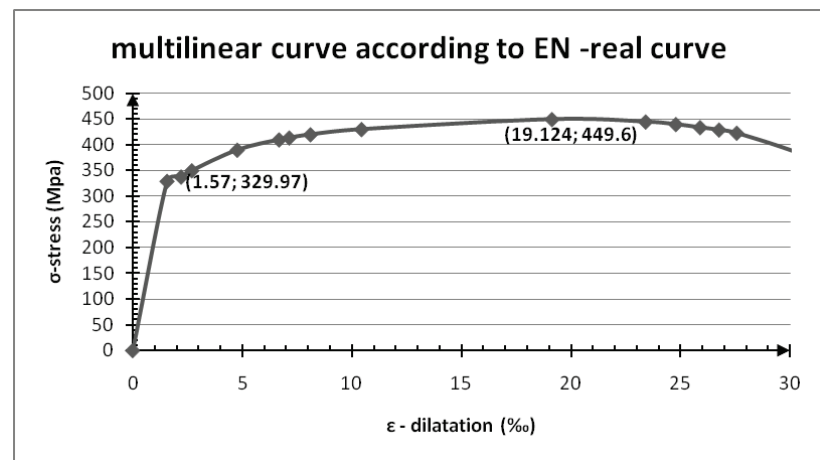

Figure 7 EN1993-1-5- multilinear curve which corresponds to the real curve of material according to Fig. 5

Multilinear curve according to BSK07, Swedish standard, demonstrated satisfactory results in work. (Braun, B. [8]). For our research, it is assumed to be as the formulae presented in Fig. 6, where the average values of stress for all the tested coupons in the experiment were considered characteristic, those being: $f_{y}=329,33 \mathrm{MPa}$ and $f_{u}=440,83 \mathrm{MPa}$ [9].

$\varepsilon_{1}=\frac{f_{y}}{E}=0,001568$ 


$$
\begin{aligned}
& \varepsilon_{2}=0,025-5 \frac{f_{y}}{E}=0,01716 \\
& \varepsilon_{3}=0,02+50 \frac{f_{u}-f_{y}}{E}=0,04655
\end{aligned}
$$

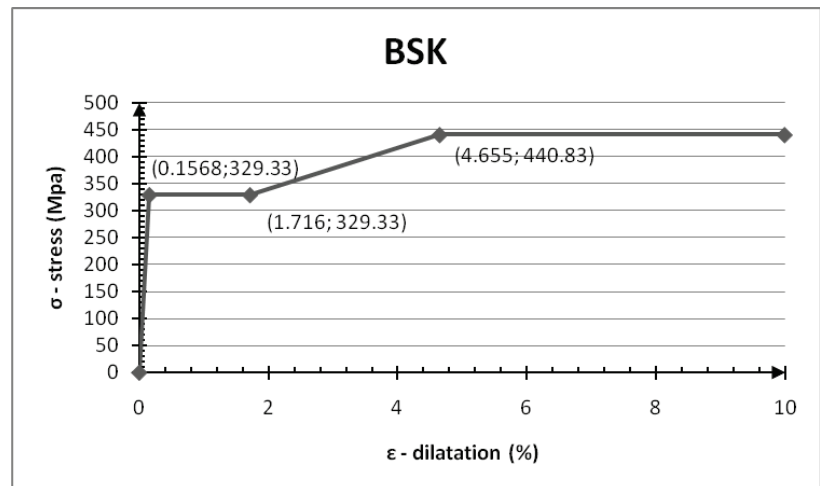

Figure 8 BSK07 (Swedish standard)-multilinear curve

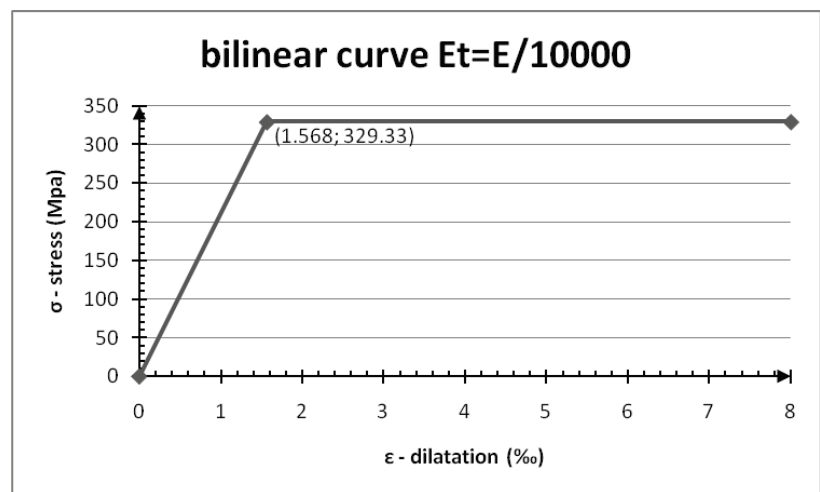

Figure 9 EN1993-1-5-bilinear curve with tangent modulus $E_{\mathrm{t}}=E / 10000$

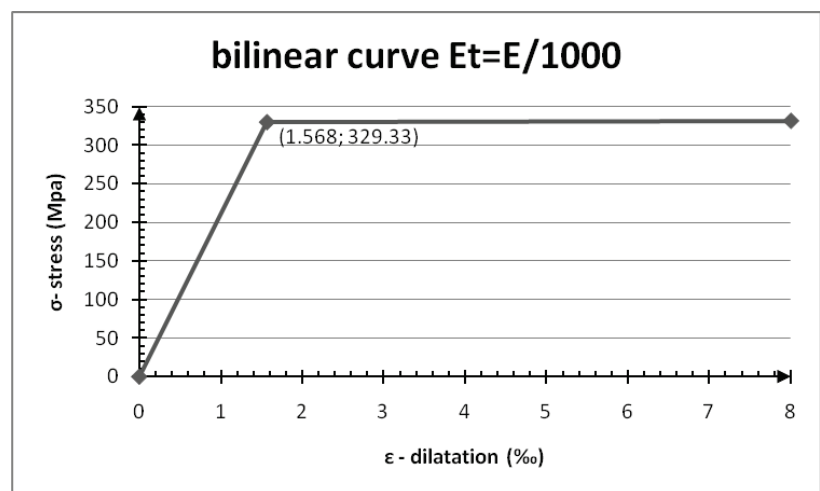

Figure 10 Bilinear curve with tangent modulus $E_{\mathrm{t}}=E / 1000$

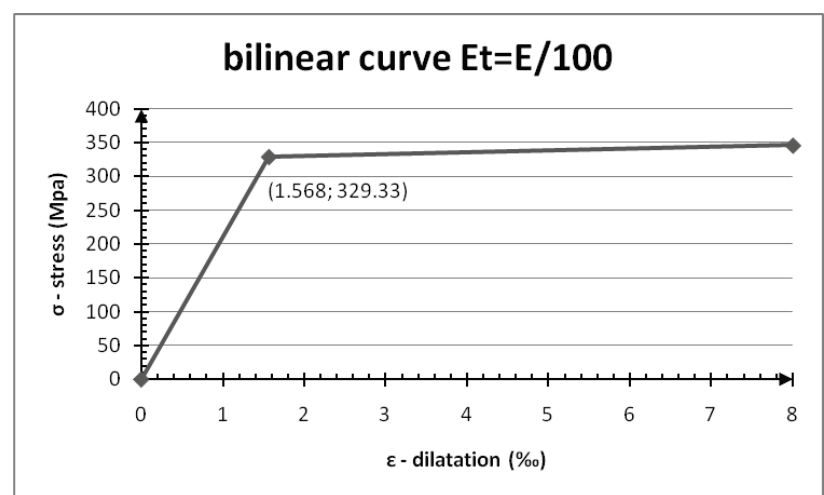

Figure 11 EN1993-1-5-bilinear curve with tangent modulus $E_{\mathrm{t}}=E / 100$

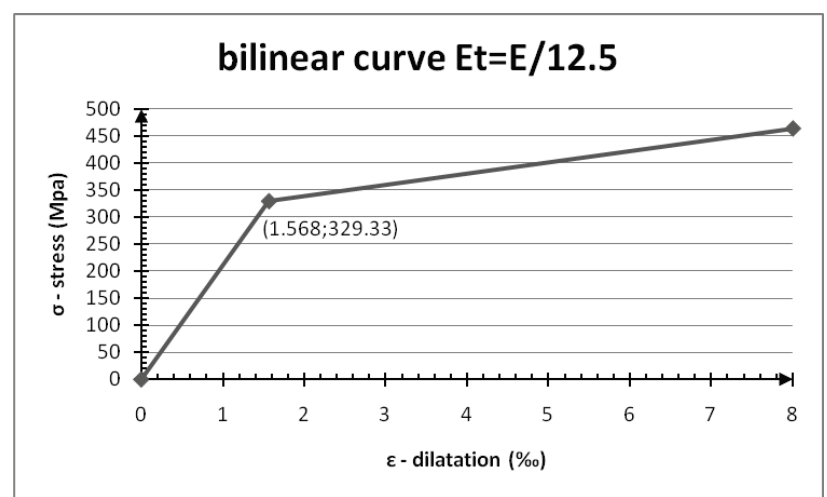

Figure 12 Bilinear curve with tangent modulus $E_{\mathrm{t}}=E / 12,5$

For the bilinear curves, further in the text, also the average value of yield stress was assumed, $f_{y}=329,33$ $\mathrm{MPa}$.

For each model, ultimate load capacity for the different material models was presented (see Tab. 2).

\subsection{Geometry of girders, limit conditions, load and finite elements grid}

Girder geometry was assigned according to the experimental models, as presented in Fig. 1, and the dimensions of the girder were presented in Tab. 1. Initial geometrical imperfections are assigned only on the girder web, while the flanges and stiffeners have no imperfections. In Fig. 13 there is a numerical model with initial imperfections on the web. The girder supports have the hemi-cylindrical form and they are restrained on the bottom side.

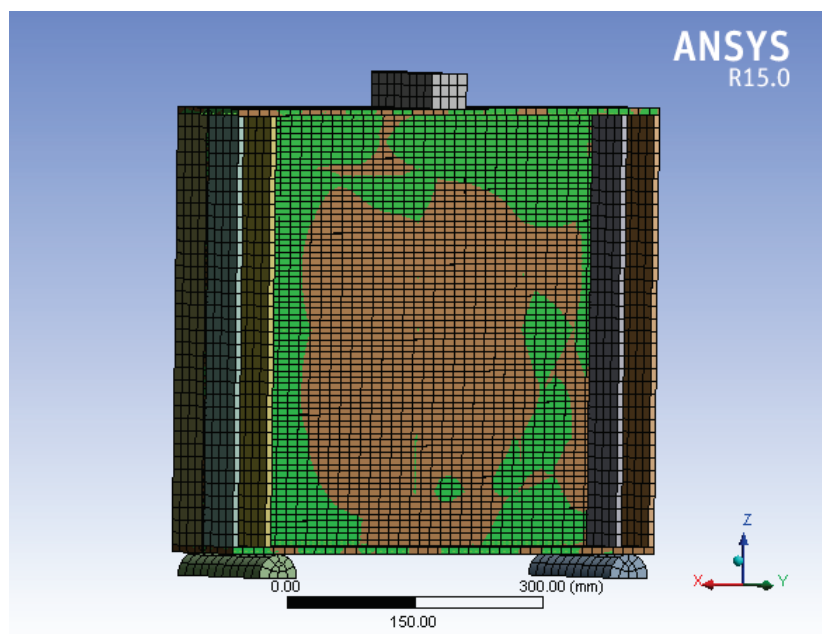

Figure 13 Initial geometrical imperfections on the numerical model

The girder load was applied through the load plate as in the experiment, and it was permitted to move only in vertical direction.

As for the values, the load was applied in steps, more precisely in six steps using the function step controls. Depending on the girder, the value of the load differed, because different values of ultimate loads were expected for each one of them, in accordance with the experimental data.

Finite element mesh was discretized and after that, the element size of $15 \mathrm{~mm}$ was adopted, see Fig. 14. Finite elements are of the SOLID 186 type. This finite element has 20 nodes with three degrees of freedom per a 
node, and those are displacements in axial directions $x, y$ and $z$. It is very useful for non-linear analysis. The model of the girder with the adopted finite element mesh is presented in Fig. 14.

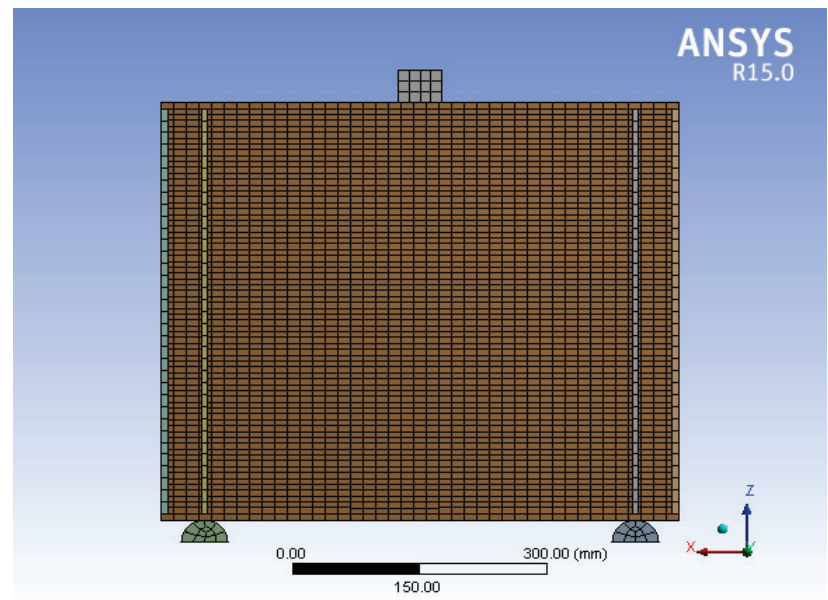

Figure 14 Finite element mesh, SOLID 186, with the element size of 15

\section{Determination of the girder ultimate load}

One of the main goals of this modelling is determination of the girder ultimate load value. In this section, determination of ultimate load of four types of girders with six different material models is presented. The obtained results are compared with the experimental results, and an analysis of the obtained results was performed. Increase of the ultimate load capacity with increase of length of loading and with the influence of stiffeners is presented.

In the numerical analysis, the criterion for ultimate load is that load at which the solutions start to diverge and when the girder starts to lose stability and exhibits abrupt build-up of deformations. Fig. 15 displays development of total deformation with gradual increase of force for A1 girder type, for the material model in accordance with EN1993-1-5 (see Fig. 7). Deformations gradually increase up to the value of $9.5 \mathrm{~mm}$ which corresponds to the load of $178,174 \mathrm{kN}$, and after that, the deformation abruptly increases and the solution diverges. Since after this value the girder loses stability, exactly this value of $178,174 \mathrm{kN}$ was assumed to be the ultimate load.

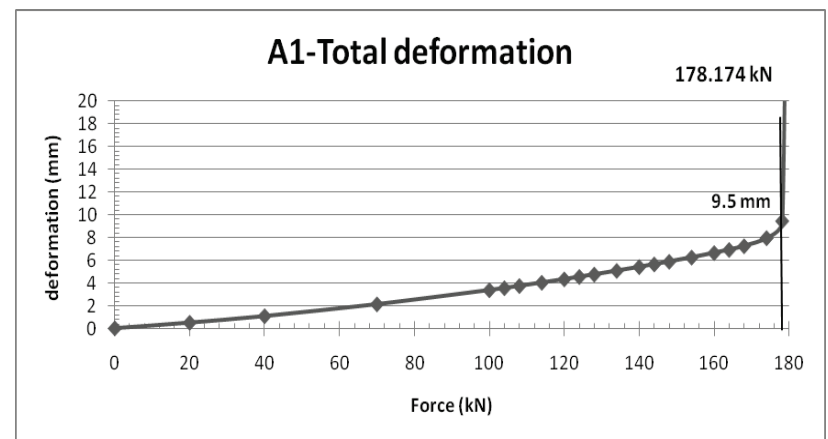

Figure 15 Development of total deformation with the increase of force for the girder A1

In Fig. 16 we can see a display of total deformation at ultimate load on the numerical model.
Fig. 17 presents the diagram of increase of VonMises stresses with the increase of force until the ultimate load for the A1 girder type is reached. At the force value of $178,174 \mathrm{kN}$, the highest stress value of $440,59 \mathrm{MPa}$ is reached, while the tensile strength of steel is $f_{u}=449,6$ $\mathrm{MPa}$.

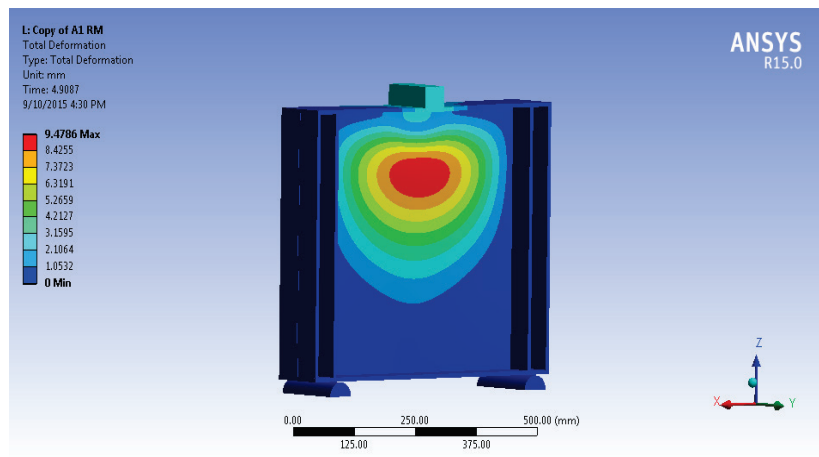

Figure 16 Total deformation of the girder A1 for the value of ultimate load of $178,174 \mathrm{kN}$

In Fig. 17 it can be observed that at the force value of $92,96 \mathrm{kN}(52,17 \%$ of the ultimate load $)$ the yield stresses $\left(f_{y}=329,97 \mathrm{MPa}\right)$ were reached in certain points. Stress reaches the maximum value for the obtained value of ultimate load, and abruptly decreases after that.

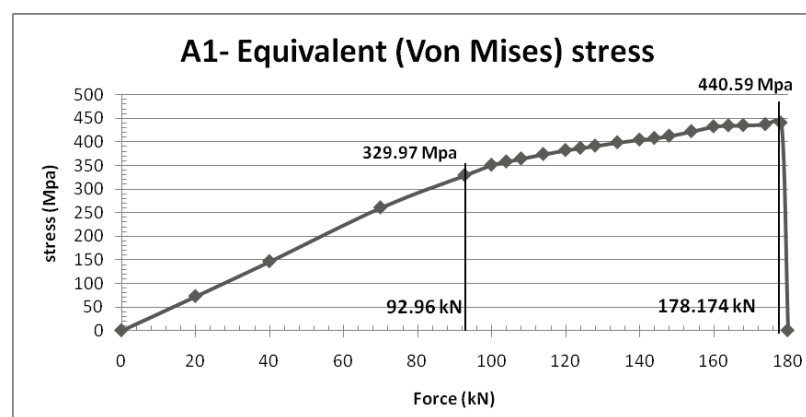

Figure 17 Diagram of Von-Mises stresses with the increase of force for the A1 girder

Presentation of the status of Von-Mises stresses on the numerical model for the ultimate load of A1 girder is provided in Fig. 18.

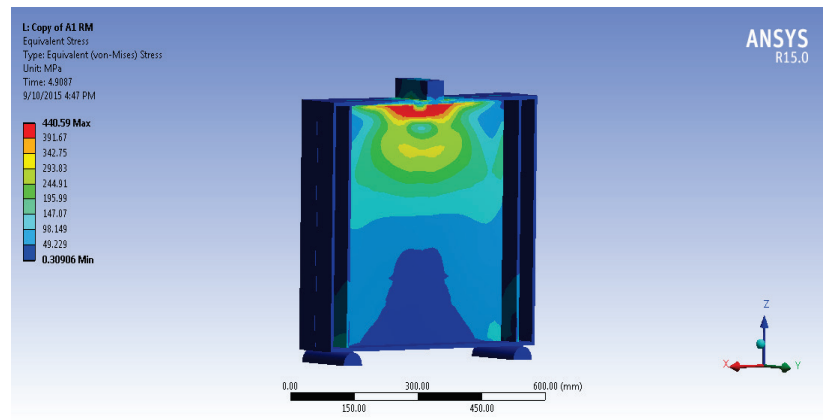

Figure 18 Presentation of Von-Mises stress state of A1 girders for the force of $178,174 \mathrm{kN}$

Figs. 15 and 17 display the values of deformations and stresses for A girders for the material model with multilinear curve in accordance with EN1993-1-5 (see Fig. 7). 
In the same way, ultimate loads were obtained for other types of girders as well, as for other material models

The analysis of the values of ultimate loads for all the types of girders and various material models was performed, by comparing these results with experimental results of the material models which are proposed in current European standards, whereby both the bilinear curve with the tangent modulus $E_{\mathrm{t}}=E / 1000$ and the bilinear curve with the tangent modulus $E_{\mathrm{t}}=E / 12,5$ were taken into account because of additional research.

Values of the ultimate loads in $\mathrm{kN}$ for all four types of girders (girder A1, A2, A3 and A7) are presented in
Tab. 2. Primarily, what is presented is the value of ultimate load obtained experimentally.

Other rows present ultimate loads obtained by the numerical simulation for each of various material models, and immediately below one may see the deviation from the experimentally obtained value.

The numbers display the values of the ultimate loads, expressed in $\mathrm{kN}$, and the load difference in respect to the ultimate loads obtained experimentally is presented in percents. The last column presents the average value of deviation expressed in percents for each of the assigned material models.

Table 2 Ultimate load values for all types of girders in $\mathrm{kN}$

\begin{tabular}{|c||c|c|c|c|c|}
\hline Material models & A1 & A2 & A3 & A7 & Average value (\%) \\
\hline \hline Experiment (100\%) & 165 & 215 & 183 & 255 & - \\
\hline Multi. $E N$ & 178,174 & 216,9275 & 188,5 & 274 & - \\
\hline$\Delta(\%)$ & 7,98 & 0,90 & 3,01 & 7,45 & 4,84 \\
\hline$B S K$ & 162 & 196,297 & 164,472 & 262 & - \\
\hline$\Delta(\%)$ & $-1,82$ & $-8,70$ & $-10,12$ & 2,75 & - \\
\hline$E / 10000$ & 172 & 235,406 & 176,962 & 299,407 & 8,85 \\
\hline$\Delta(\%)$ & 4,24 & 9,49 & $-3,30$ & 17,41 & - \\
\hline$E / 1000$ & 174 & 235,642 & 177,396 & 302,591 & \\
\hline$\Delta(\%)$ & 5,45 & 9,60 & $-3,06$ & 18,66 & \\
\hline$E / 100$ & 180,5 & 238,637 & 185,5 & 302,438 & - \\
\hline$\Delta(\%)$ & 9,39 & 10,99 & 1,37 & 18,60 & \\
\hline$E / 12,5$ & 216 & 261,906 & 252 & 338,524 & 10,09 \\
\hline$\Delta(\%)$ & 30,91 & 21,82 & 37,70 & 32,75 & - \\
\hline
\end{tabular}

In Tab. 2 can be seen that all material models provided satisfactory congruence, except for the material model with tangent modulus $E_{\mathrm{t}}=E / 12,5$ (see Fig. 12), so it can be concluded that it is not favourable for this type of analysis and it will not be further considered.

On the other hand, the best congruence was exhibited by the material model with the multilinear curve according to EN1993-1-5 (Fig. 7), whose deviation is $4,84 \%$ in average for all the girder types.

Analysis of the obtained results provided the values of increase of ultimate load capacity for the cases when the longitudinal stiffener is added to girder. An increase of the ultimate load capacity for the girders having the patch loading length of $50 \mathrm{~mm}$ (A1 and A3) and of 150 $\mathrm{mm}$ (A2 and A7) for different material models, is presented in Fig. 19 and Fig. 20

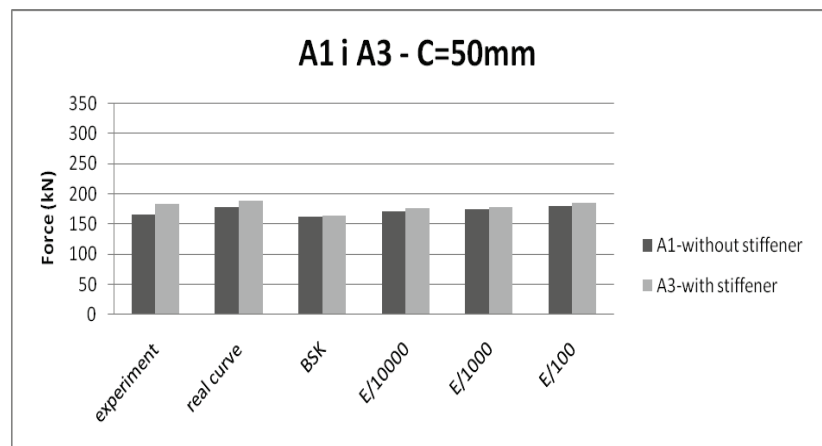

Figure 19 Impact of longitudinal stiffener on the ultimate load capacity for $c=50$

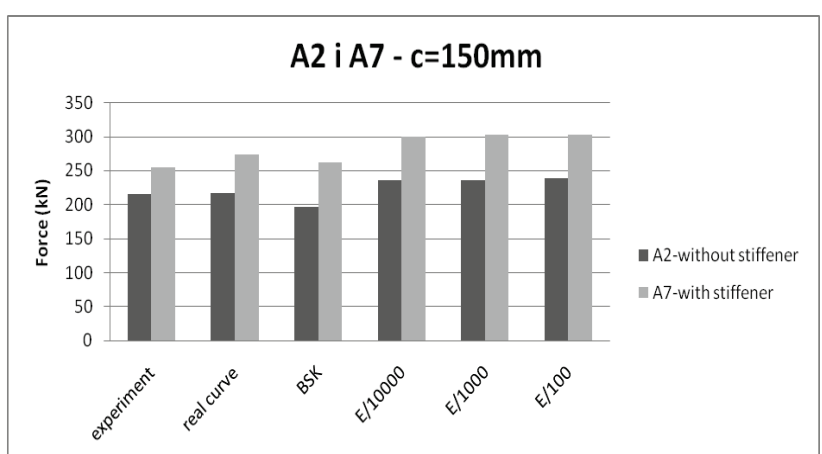

Figure 20 Impact of longitudinal stiffener on the ultimate load capacity for $c=150$

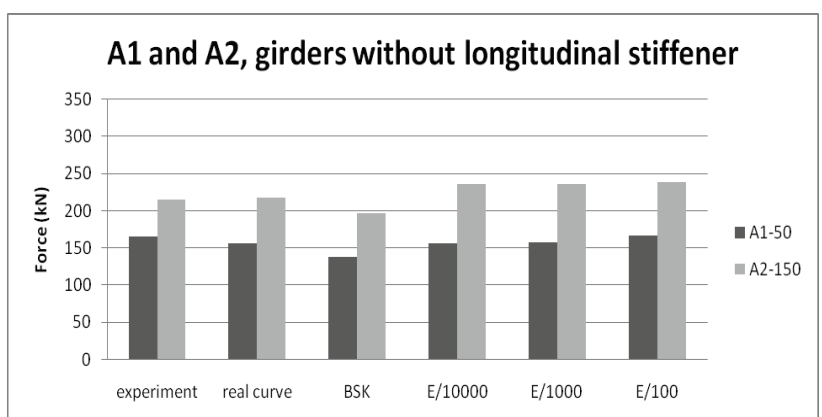

Figure 21 Increase of ultimate load capacity when the length of patch loading is increased from $50 \mathrm{~mm}$ to $150 \mathrm{~mm}$ for the girders without longitudinal stiffener

In the following diagrams one presents an increase of ultimate load capacity when the length of patch loading is increased from $50 \mathrm{~mm}$ to $150 \mathrm{~mm}$. In the first diagram, Fig. 21, the girders without the longitudinal stiffener were presented (A1 and A2), and on the other diagram, Fig. 22 
the diagrams for the girders with the longitudinal stiffener were presented (A3 i A7), for different material models.

Tab. 3 presents an analysis of the results of increase of the ultimate load capacity. The first two columns present an increase of ultimate load capacity in percents, if the longitudinal stiffener is added to the girder. The girders having the length of patch loading of $50 \mathrm{~mm}$ are in the first column and in the second column those having the length of patch loading of $150 \mathrm{~mm}$. The third and fourth column present increase of ultimate load capacity when the length of patch loading is increased from $50 \mathrm{~mm}$ to $150 \mathrm{~mm}$. The girders without stiffener are in third column and the girders with stiffener are in the fourth.

\section{$A 3$ and $A 7$, girders with longitudinal stiffener}

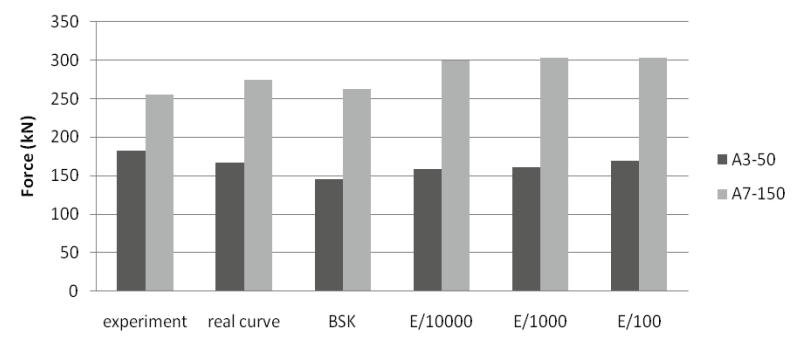

Figure 22 Increase of ultimate load capacity when the length of patch loading is increased from $50 \mathrm{~mm}$ to $150 \mathrm{~mm}$ for the girders with longitudinal stiffener

Table 3 Increase of ultimate load capacity when the length of patch loading is increased and longitudinal stiffener is present, expressed in percents

\begin{tabular}{|c||c|c|c|c|}
\hline \multirow{2}{*}{ Material models } & \multicolumn{2}{|c|}{$\begin{array}{c}\text { Increase of ultimate load capacity when the } \\
\text { longitudinal stiffener is present (\%) }\end{array}$} & $\begin{array}{c}\text { Increase of ultimate load capacity when the length of } \\
\text { patch loading is increased from } \\
c=50 \div 150 \text { mm (\%) }\end{array}$ \\
\hline & $c=50 \mathrm{~mm}$ & $c=150 \mathrm{~mm}$ & Without stiffener & With stiffener \\
\hline & $\mathrm{A} 1 \mathrm{i} \mathrm{A} 3(\%)$ & $\mathrm{A} 2 \mathrm{i} \mathrm{A} 7(\%)$ & $\mathrm{A} 1 \mathrm{i} \mathrm{A} 2(\%)$ & A3 i A7 (\%) \\
\hline \hline Experiment & 9,84 & 15,69 & 23,26 & 51,20 \\
\hline Multi. $E N$ & 5,8 & 20,83 & 17,86 & 39,66 \\
\hline$B S K$ & 1,53 & 25,08 & 17,47 & 40,90 \\
\hline$E / 10000$ & 2,88 & 21,38 & 26,93 & 41,37 \\
\hline$E / 1000$ & 1,95 & 22,13 & 26,16 & 38,67 \\
\hline$E / 100$ & 2,77 & 21,10 & 24,36 & 43,56 \\
\hline Average value & 2,99 & 22,10 & 22,56 & \\
\hline
\end{tabular}

\section{Conclusion}

This paper forms appropriate numerical models in the software package ANSYS Workbench 15, which in a best way describe experimental models. The goal of this research is obtaining of results which would be used in practical application to select the most favourable material model for analysis, in agreement with the European standards.

By analysing the obtained results, it was concluded that all material behaviours curves provided satisfactory results apart from the curve with the tangent modulus $E_{\mathrm{t}}=$ $E / 12,5$.

The best congruence with the experimental results was exhibited by the material model corresponding to the multilinear curve of real material, and the average deviation for all types of the girder amounts to 4,84\%. The material model which corresponds to the bilinear curve with tangent modulus $E_{\mathrm{t}}=E / 12,5$ deviates $30,80 \%$, so it can be concluded that it is not favourable for this type of analysis.

When analysing the results, the following facts must be taken into account: initial geometrical imperfections are assumed to be present only on the web, the characteristics of the material for the real curve, as well as the yield stress $f_{y}$ and tensile strength $f_{u}$ are assumed as the average value of the tested coupons, the material characteristics of the flanges and the webs were assumed to be the same (which was not the case in the experiment), the impact of the welds and initial geometrical imperfections of flanges and stiffeners was ignored, it is impossible to accurately set boundary conditions etc.

By taking this into account, it can be said that satisfactory congruence of the results obtained experimentally and by the numerical analysis was achieved.
Behaviour of plate girders under the action of patch loading is very complex and depends on various parameters $[10,11]$. Also, the stress analysis which is previously conducted indicates the onset of plasticization starts as early as after 58,5\% in comparison to the ultimate load (in average, for all the girders). As presented, deformations occurring then need not be considerable. Plasticization develops at the most loaded section of the web, firstly only on the surface, and then expanding across the thickness of the web [12].

This indicated that two combinations should be analysed for every structure:

- Girder constructed of high grade steel, with a higher yield strength and a slender web;

- Girder constructed of low grade steel, with a thick web.

Parameters leading to the increase of the ultimate load were analysed and the conclusion is that the ultimate load is increased along with the increase of the length of the load from $50 \mathrm{~mm}$ to $150 \mathrm{~mm}$, more than when a longitudinal stiffener is added to the girder. [13].

This conclusion can have a practical application. On the event of assembling the bridges, when a bridge is being slid into designed position over the temporary or permanent supports, it is desirable to increase the contact surface of the girder and support which would increase the ultimate strength of the girders.

\section{References}

[1] ANSYS 15, LS-DYNA Keyword user`s manual, Vol I, II, III, 2013, Version R7.0, Livermore Software Technology Corporation.

[2] EN 1993-1-5: 2006 Eurocode 3: Design of steel structures, Part 1-3: Plated structural elements, 2006. 
[3] BSK07, Boverkets handbok om stålkonstruktioner BSK 07, 2007. (in Swedish).

[4] Mijušković, O.; Ćorić, B. Patch loading-analytical approach to critical load determination. // Građevinar. 65, 1(2013), pp. 1-10.

[5] Lučić, D. Prilog analizi stabilnosti tankozidnih nosača. Doktorska disertacija, Građevinski fakultet u Beogradu, 1999.

[6] Marković, N. Izbočavanje limenih nosača pod dejstvom lokalnog opterećenja. Doktorska disertacija, Građevinski fakultet u Beogradu, 2013.

[7] Johansson, B.; Maquoi, R.; Sedlacek, G.; Müller, C.; Beg, D. Commentary and worked examples to EN 1993-1-5. Plated structural elements. // JRT Scientific and Technical Reports, (2007).

[8] Braun, B. Stability of steel plates under combined loading. Doctoral Thesis, Nr 2010-3, Institut für Konstruktion und Entwurf Stahl-Holz- und Verbundbau, Universität Stuttgart, 2010.

[9] Turnić, D. Nelinearno ponašanje i granična nosivost limenih nosača opterećenih lokalizovanim opterećenjem. Doktorska disertacija, Građevinsko-arhitektonski fakultet u Nišu, 2016.

[10] Čaušević, M.; Bulić, M. Stabilnost konstrukcija. Golden marketing, 2013.

[11] Markovic, N.; Hajdin, N. A Contribution to the Analysis of the Behaviour of Plate Girders subjected to Patch Loading. // Journal of Constructional Steel Research. 21, (1992), pp. 163-173. https://doi.org/10.1016/0143-974X(92)90025-A

[12] Marković, N.; Turnić, D.; Igić, T. Elasto-Plastic Behaviour and Ultimate Load of Plate Girders Subjected to Patch Loading. // Fourth Serbian $\left(29^{\text {th }} \mathrm{Yu}\right)$ Congress on Theoretical and Applied Mechanics / Vrnjačka Banja, 2013, D-31, pp. 741-746.

[13] Hajdin, N.; Marković, N. Influence of the length of patch load on the ultimate load of plate girders. // Zbornik radova IX. kongres Saveza društava građevinskih konstruktera Jugoslavije / Cavtat, 1991, pp. 39-44.

\section{Authors' addresses}

Dragana Turnić, PhD, Assistant

Faculty of Civil Engineering and Architecture,

University of Niš,

Aleksandra Medvedeva 14, 18000 Niš, Serbia

+381642282598 / dragana.turnic@gaf.ni.ac.rs

Nenad Marković, PhD, Assistant Professor

Faculty of Civil Engineering,

University of Belgrade,

Bulevar kralja Aleksandra 73, 11000 Belgrade, Serbia

+38113218524/nenad@grf.bg.ac.rs

Tomislav Igić, PhD, Full Professor (retired)

Faculty of Civil Engineering and Architecture, University of Niš,

Aleksandra Medvedeva 14, 18000 Niš, Serbia

+38118588200 / tomislav.igic@gaf.ni.ac.rs

Vlastimir Nikolić, PhD, Full Professor

Faculty of Mechanical Engineering,

University of Niš,

Aleksandra Medvedeva 14, 18000 Niš, Serbia

+38118257970/ vlastimir.nikolic@ni.ac.rs

Marija Spasojević Šurdilović, PhD, Assistant Professor

Faculty of Civil Engineering and Architecture,

University of Niš,

Aleksandra Medvedeva 14, 18000 Niš, Serbia

+38118588200 /

marija.spasojevic.surdilovic@gaf.ni.ac.rs 